\title{
Human capital management and performance of community-based health planning and service (CHPS): a mediator analysis
}

\author{
Rejoice Wodomdedzi Foli \\ ABSA Bank Ghana Ltd., Accra, Ghana, and \\ Livingstone Divine Caesar \\ Department of Maritime Administration, Texas A\&M University at Galveston, \\ Galveston, Texas, USA
}

Human capital management

Received 26 April 2021 Revised 7 September 2021 9 October 2021 Accepted 11 October 2021

\begin{abstract}
Purpose - This paper aims to examine the complexity of the relationship between human capital management (HCM) and the performance of community-based health planning and services (CHPS) from an emerging market perspective. It further explores the mediating role of community orientation; institutional intervention and capability of resources in the hypothesized relationship between HCM and the performance of CHPS.

Design/methodology/approach - Quantitative data was collected (through a survey) from 210 health volunteers using a systematic random sampling technique. A 95\% response rate was realized and the data was analyzed using exploratory and confirmatory factor analysis and hierarchical multiple regression.

Findings - HCM has a direct relationship with the performance of the CHPS model. It also emerged that institutional intervention and capability of resources partially mediate the relationship between HCM and CHPS performance; while community orientation fully mediates the same relationship.

Practical implications - Capacity building for staff must be wired into the workings of the CHPS model to yield the maximum impact. This points to the need for training packages that focus on building both social and cultural competence for staff working among locals under the CHPS model. Effective planning is, thus, needed to ensure a seamless allocation of adequate resources to boost performance. Also, community engagement is critical to the success of the CHPS model as it could serve as a platform for awareness creation among locals.

Originality/value - This paper introduces community orientation, institutional intervention and capability of resources as mediating variables to investigate the hypothesized relationships. It offers a developing country insight into how HCM-related factors might be impacting the performance of communitybased health programs.
\end{abstract}

Keywords Community orientation, Human capital management, Resource capability,

Institutional intervention, Performance of CHPS,

Community health-based planning and services model (CHPS)

Paper type Research paper

(C) Rejoice Wodomdedzi Foli and Livingstone Divine Caesar. Published in Vilakshan - XIMB Journal of Management. Published by Emerald Publishing Limited. This article is published under the Creative Commons Attribution (CC BY 4.0) licence. Anyone may reproduce, distribute, translate and create derivative works of this article (for both commercial and non-commercial purposes), subject to full attribution to the original publication and authors. The full terms of this licence maybe seen at http://creativecommons.org/licences/by/4.0/legalcode
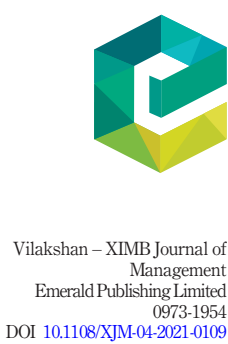
Given its inherent ability to offer organizations a seemingly inimitable source of competitive advantage, human capital ( $\mathrm{HC})$ is increasingly being deployed as a tool for value creation, growth and survival among firms (Ali et al., 2016). Regarded as the collection of knowledge, skills and experience individual gains through education and training, $\mathrm{HC}$ positively impacts other resources of an organization in both the short and long term. Consequently, firms that will succeed in the marketplace must create an intellectual capital management system that is consciously designed to improve its $\mathrm{HC}$ resources. An effective management of the $\mathrm{HC}$ resources is, thus, critical to the continued existence of both public and private sector organizations and their customer offerings.

Similar to what pervades in other Sub-Saharan African countries, Ghana's public health sector is confronted with a multiplicity of challenges - high maternal and child mortality rates, poor infrastructure and unequal access to medical care (Saleh, 2012). To address the aforementioned problems and others such as the structural exclusion of rural folks (Teye et al., 2014), Ghana adopted the community-based health planning and services (CHPS) model. Among other things, the CHPS model sought to address health care delivery challenges that had their roots in human capital management (HCM) shortcomings (Awoonor-Williams et al., 2018). Given the HC limitations of Ghana's health care delivery system, this paper sought to evaluate how HCM could impact the performance of the CHPS model which was introduced to improve access to health care among citizens. It also investigates how institutional interventions, community orientation and resource capability impact the relationship between HCM and CHPS performance.

\section{Literature review}

The CHPS model

Community-Based Health Planning and Services (CHPS) model is a community action where nurses undertake home visits and do community durbars and community education, health promotion and immunization (Kweku et al., 2020). The CHPS idea partitions a community into CHPS zones, which might be around five communities meeting up as one zone. The model comprising of the community health the board advisory groups, the volunteers and the health compounds to help improve access to health in local communities by the Ghana Health Service. This model was developed to address the underlying social, environmental and economic causes of poor health.

\section{Human capital management and performance}

$\mathrm{HCM}$ is critical to the growth and survival of organizations; as it encourages the initiation of processes for the assessment and satisfaction of future manpower requirements. HCM consequently provides the basis for developing policies and practices that enhance the inherent capacities of people, their skill development and employability through continuous learning (Kulkarni et al., 2020). HCM is, thus, a critical aspect of performance management among employees. According to Rudman (2020), performance management entails an integration of HCM practices with the organization's business goals and must align with the $\mathrm{HC}$ activities and culture of the firm. It is, thus, difficult to effectively manage a firm's HC without a system that measures performance and performance capability. Lee et al. (2010) uncovered six underlying HRM practices (such as training and professional development) that improve the business performance of a firm as well as the productivity of its employees. 
Figure 1 depicts the conceptual framework of CHPS performance, underpinned by the expectancy and HC theories (Baron and Armstrong, 2007; Salaman et al., 2005; Vroom, 1964). The mediating variables, namely, community orientation, institutional intervention and capability of resources are thought to directly mediate the relationship between $\mathrm{HC}$ and CHPS performance.

\section{Hypotheses development}

\section{Human capital management and performance of CHPS}

$\mathrm{HCM}$ is a creative approach to handle resources, viewing them as an asset rather than expenses. HC consists of the intangible resources that workers provide for their employers. Bontis et al. (1999)M explain it as the human factor in the organization; the combined intelligence, skills and expertise that gives the organization its distinctive character. The human elements of the organization are those that are capable of learning, changing, innovating and providing the creative thrust that if properly motivated, can ensure the longterm survival of the organization.

Based on the assertion of Baron and Armstrong (2007), it is natural to infer that organizations are able to improve performance through a complementary blend of HCM and HRM as they must be seen as two necessary components combining their activities and results in the complex process of people management. The logic behind HCM and organizational performance stem from the orthodoxy that employee performance improves when organizations invest in the development of the skill set of their staff (Crook et al., 2011; Jain and Ahuja, 2019). Highly skilled staff positively impacts on the performance of the organization. Hence, the effective management of the $\mathrm{HC}$ can help in the development of

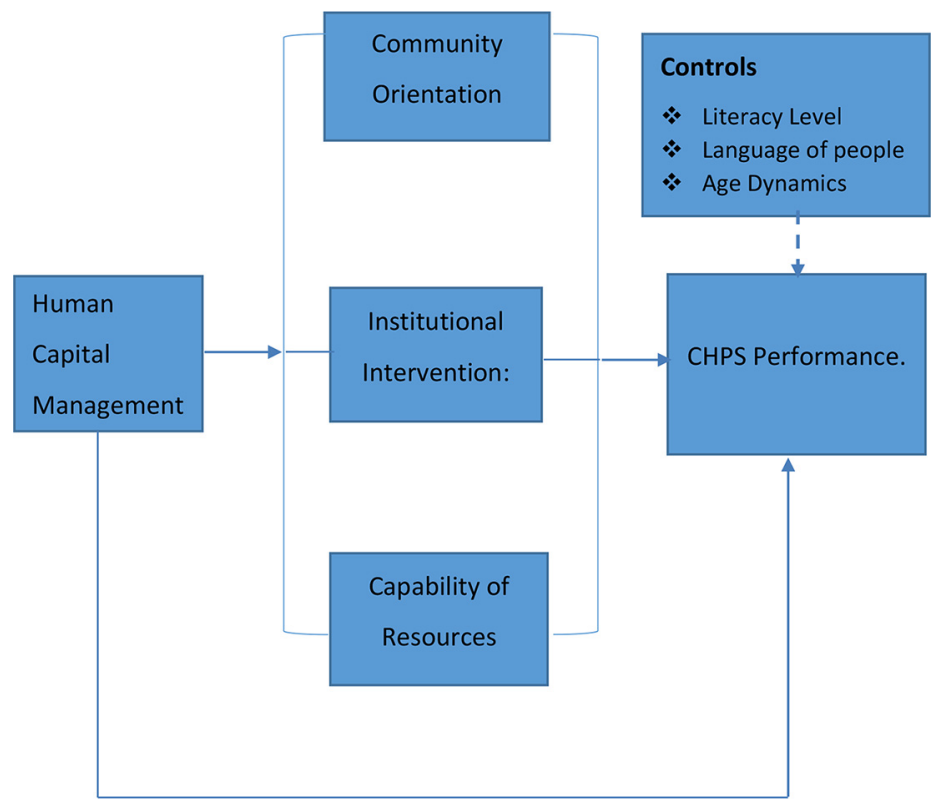

Source: Author's construct, 2020

Figure 1. Conceptual model 
employee skill sets and abilities that can be channeled to the enhancement of the CHPS model. It is, thus, hypothesized that:

H1. HCM has a positive impact on CHPS performance.

Community orientation and performance of CHPS

Community orientation as per the study are proposed to include organizing, accessibility and affordability. According to Desseler (2007), before information on a service or product is accepted and used by the people, they should be given awareness, oriented and educated to alleviate wrong perceptions or confusions on the service or product. Awareness is created when the community is organized and this motivates the people to act on their problems to find solutions. Informing community leaders under the CHPS program is, therefore, a necessity. The need to engage in community orientation ensures that the $\mathrm{HC}$ of the organization is effectively exploited. For most community projects, effective management of the $\mathrm{HC}$ resources results in effective engagement and orientation of the community, which may impact positively on success, and thus, performance (Proenca et al., 2000). Expert knowledge provided to the community helps to adequately equip the locals with requisite skills that are critical to the advancement and success of such projects. It is, thus, hypothesized that:

H2. Community orientation mediates the relationship between HCM and CHPS performance.

\section{Institutional interventions and performance CHPS}

This paper contends that the HCM influences on the intervention of institutions will enhance the performance of the CHPS Model. According to Abor et al. (2008), institutional intervention at the community level encourages local residents to come up with flexible, financially sustainable approaches that can eventually lead to lasting, meaningful societal changes and partner to create value. Chatzkel's (2004) concept on realities of institutional intervention and its impact on performance, perhaps, points to how the construct might mediate a relationship between HCM and CHPS performance. As Chatzkel (2004) posits, institutions are nothing more than an extension of human thought and action. It is the knowledge, skills and abilities of individuals that create value and the focus has to be on means of reacting, retaining, developing and maintaining the $\mathrm{HC}$ as an aspect of institutions to improve performance. With astute HCM, organizations are able to impart critical skills to staff at the local level which helps them to effectively exploit resources provided through institutional interventions for the success of the CHPS model (Heravi et al., 2015). It is, thus, hypothesized that:

H3. Institutional interventions mediate the relationship between HCM and the performance of CHPS.

\section{Resource capability and performance of CHPS}

Resource capability includes skills, knowledge, ability and experience of individual team members and their ability to grow and innovatively possessed by people in an organization (Donate et al., 2016). Also, resource capability is the resourcefulness of the members of the team who possess and exhibit the $\mathrm{HC}$ skills they have to add value and improve 
performance. A resourced team will have a higher capability if each team members possess unique skills, knowledge and experience. The dynamism of the team allows for the exhibition of complementary behaviors and abilities, expressed through organizational processes to enable a business to anticipate changing market conditions and accordingly respond to remain competitive. Logically, building resource capability comes through training and serves as an incentive for $\mathrm{HC}$ development leading to an increase in CHPS performance. Resource capability can be enhanced as per this study through the provision of incentives and training of $\mathrm{HC}$, which will improve CHPS performance. It is, thus, hypothesized that:

\section{H4. Resource capability mediates the relationship between HCM and CHPS performance.}

\section{Methodology, sampling and procedures}

A cross-sectional survey was done to gather the required data for the study in a defined population of 784 volunteers in 5 regions considered as CHPS active zones in Ghana. The objective of the survey was to collect numerical data from the respondents to test the relationship among the variables. Once the pilot survey was successful, the questionnaire was confirmed to be reliable and valid. Saunders et al. (2012) recommend that $10 \%-20 \%$ of the actual sample for a study should be used to pre-test the instrument. Pre-testing was necessary to spot and proper any bias and weakness before the administration of the survey. In line with that, 20 respondents were used given that the sample size is 200 . Reliability of the data collection instrument was checked using the Cronbach's alpha values. The general rule range of +0.5 to +0.9 was applied (Taber, 2018). The reliability results are presented in the data analysis section. Relevant questions to test each of the identified variables were developed and grouped appropriately. A five-point Liker scale was adopted to measure variables that could not be observed as discrete values. The five-point Likert scale also contributes to improving the construct validity (Bandalos, 2014). A structured questionnaire that had closedended questions were used to achieve a standardized response pattern and aid easy coding.

Most measures in the questionnaire were chosen from those that had been used in previous research. For instance, the 16 scale items used for measuring HCM was adapted from Baron and Armstrong (2007) registering a Cronbach's alpha value of 0.855. Likewise, measures for community orientation were adapted from Proenca et al. (2000) and had a Cronbach's alpha value of 0.684 . Institutional intervention was measured with six items adapted from Abor et al. (2008) with Cronbach's alpha value of 0.817. Resource capability was measured with four items adapted from Crook et al. (2011) and Jain and Ahuja (2019). The scale had a Cronbach's alpha value of 0.827 . CHPS performance five items adapted from Wright et al. (2003) and had a Cronbach's alpha value of 0.829 .

The study selected 200 (using simple random sampling technique which is a form of probability sampling that helps achieve representativeness of sample) respondents from a total population of 784 volunteers in five regions considered as CHPS active zones in Ghana. The actual sample size was calculated using the total population size, confidence level of $95 \%$ and a margin of error of $6 \%$. After the calculation, a sample size of 200 respondents was realized. The sample size, thus, corresponds to the recommended numbers given in Saunders et al. (2012).

The data was collected through field administration of 210 questionnaires to take care of non-response issues and missing data. After 2 months, 210 questionnaires were received representing 100\% response rate. The survey was conducted between 22 September 2019 and 24 February 2020. Also, ethical steps were taken to control for errors and biases. Common method bias was assessed using the recommendation by Podsakoff and Organ (1986). The results showed that the first factor accounted for $28.588 \%$ of the total variance.

Human capital management

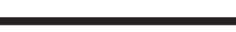


This means that there was no problem with common-method variance. All ethical protocols were followed for the study. All data was analyzed using SPSS where one-way analysis of variance and a covariance structural equation modeling that is used to confirm the dimensionality and assess the reliability and validity of the measurements.

\section{Results and findings}

Demographic information

The distribution of the demographic characteristics related to the respondents is shown in Table 1 . The table indicates a male to female ratio of 34.5\%:65.5\%. This suggests that women are dominant within the health profession space, especially with regard to the CHPS program than men. It is particularly so as the CHPS focuses more on nurses and midwives in providing first aid health assistance to rural folks. Similarly, Grant et al. (2004), found that the top health occupations dominated by women include but are not limited to nursing and midwifery. Also, $144(72 \%)$ of respondents had attained a tertiary level of education and 31 $(15 \%)$ had attained a second cycle level of education.

\section{Exploratory factor analysis}

The exploratory factor analysis was carried out using the principal component analysis using varimax rotation. The Kaiser-Meyer-Olkin (KMO) and Bartlett's Test of Sphericity results $(\mathrm{KMO}=0.865 ; \mathrm{df}=2,278 ; p<0.05$; Approx.: Chi-Square = 10,318.97; $\mathrm{df}=2,278$; $\operatorname{sig}=0.000$ ) shows the adequacy of sampling and applicability of factor analysis (Hair et al., 2012). The resultant analysis showed five factors explaining $51.6 \%$ of the variance. Table 2 gives the pattern matrix showing the factor loadings for the variables of the study. The initial eigenvalues for each component were approximately 1 and above.

The results in Table 2 show the item cluster on the same components. The results suggest that Factor 1 is community orientation; Factor 2 is institutional intervention, Factor 3 is CHPS performance, Factor 4 is HCM and Factor 5 is the capability of resources with eigenvalues of 19.440, 6.821, 3.796, 2.860 and 2.171., 1.905, 1.326 and 1.026, respectively.

\section{Confirmatory factor analysis}

A confirmatory factor analysis (CFA) was carried out to assess the validity of the measures. This approach is well-established in the marketing literature (Doney and Cannon, 1997). Six model fit indices were used to assess the overall goodness-of-fit of the model as shown in Table 3. All the model indices were within the accepted levels, confirming the measurement

Table 1.

Demographic characteristics $(n=200)$

\begin{tabular}{lcr}
\hline Demographic variables & Frequency & $(\%)$ \\
\hline Sex & & \\
Male & 69 & 34.5 \\
Female & 131 & 65.5 \\
Education & 5 & \\
Primary & 18 & 2 \\
Middle/JHS/basic & 31 & 9 \\
SHS/secondary/vocational/technical & 144 & 72 \\
Tertiary & 1 & 1 \\
Certificate in general nursing & 1 & 1 \\
Certificate in community nursing & & \\
Source: Author's Estimation from Field Survey, 2020 & &
\end{tabular}




\begin{tabular}{|c|c|c|c|c|c|c|}
\hline Item & 1 & 2 & $\begin{array}{c}\text { Component } \\
3\end{array}$ & 4 & 5 & $\begin{array}{l}\text { Human capital } \\
\text { management }\end{array}$ \\
\hline $\mathrm{CO} 1$ & 0.632 & & 0.268 & & -0.125 & \\
\hline $\mathrm{CO} 2$ & 0.582 & 0.241 & 0.249 & 0.166 & -0.106 & \\
\hline $\mathrm{CO} 3$ & 0.614 & 0.174 & 0.228 & 0.137 & 0.198 & \\
\hline COR4 & 0.529 & 0.159 & 0.185 & & 0.363 & \\
\hline COR5 & 0.217 & 0.125 & 0.498 & 0.146 & 0.656 & \\
\hline COR6 & 0.278 & 0.207 & 0.356 & 0.18 & 0.536 & \\
\hline COR7 & 0.417 & 0.106 & 0.557 & 0.147 & 0.206 & \\
\hline COR8 & 0.357 & 0.505 & 0.329 & 0.189 & 0.303 & \\
\hline COR9 & 0.237 & 0.612 & & 0.193 & 0.196 & \\
\hline COR10 & 0.402 & 0.419 & 0.184 & 0.321 & 0.356 & \\
\hline ACC11 & 0.177 & & 0.713 & 0.185 & 0.285 & \\
\hline $\mathrm{ACC} 12$ & 0.267 & 0.531 & 0.561 & 0.326 & 0.299 & \\
\hline ACC13 & & 0.143 & 0.711 & 0.245 & 0.346 & \\
\hline ACC14 & 0.295 & 0.685 & 0.203 & 0.298 & & \\
\hline ACC15 & 0.312 & 0.461 & 0.227 & 0.31 & & \\
\hline AFF17 & 0.497 & 0.489 & 0.486 & 0.353 & 0.208 & \\
\hline AFF18 & 0.199 & 0.707 & & 0.28 & & \\
\hline II19 & 0.437 & 0.59 & 0.208 & 0.176 & & \\
\hline II20 & 0.563 & 0.606 & & 0.318 & & \\
\hline II21 & 0.455 & 0.634 & 0.289 & 0.38 & 0.247 & \\
\hline II22 & 0.424 & 0.409 & 0.422 & 0.298 & 0.172 & \\
\hline II23 & 0.639 & 0.509 & & 0.204 & 0.133 & \\
\hline II24 & 0.602 & 0.438 & & 0.244 & 0.169 & \\
\hline II25 & 0.663 & 0.514 & & 0.245 & 0.212 & \\
\hline II26 & 0.707 & 0.488 & & 0.17 & 0.315 & \\
\hline II27 & 0.244 & & 0.774 & 0.145 & 0.176 & \\
\hline II28 & 0.479 & 0.674 & & 0.269 & 0.158 & \\
\hline II29 & 0.643 & 0.643 & & 0.35 & 0.187 & \\
\hline CR30 & 0.56 & 0.459 & & 0.292 & 0.242 & \\
\hline CR31 & 0.208 & & 0.778 & 0.237 & 0.168 & \\
\hline CR32 & 0.645 & 0.57 & & 0.29 & 0.289 & \\
\hline CR33 & 0.484 & 0.489 & 0.333 & 0.372 & 0.431 & Table 2. \\
\hline PI34 & 0.46 & 0.571 & 0.257 & 0.283 & 0.225 & Rotated component \\
\hline PI35 & 0.731 & 0.472 & & 0.414 & 0.264 & matrix \\
\hline
\end{tabular}

model as a good fit with the data collected. Table 3 indicates that the models fit the data well. All item standardized loadings for each construct were significant $(\phi<0.001)$, which supports the dimensionality of the constructs (Kline, 2005). Figure 2 below is the pictorial depiction of the items that loaded perfectly unto their respective latent variable after the CFA.

Finally, the fit indices, the standardized loadings for the model demonstrated comparatively high loadings, ranging from $0.572-0.874$ (Figure 3), which indicates the importance of the observed variables as indicators of the constructs consequently providing unidimensional scale for the constructs their measurement scale. Figure 3 shows the results of the hypothetical relationship between the independent variable, the mediating variable and the dependent variable.

\section{Correlation analysis results}

Using the benchmark specified by Gujarati (2003) it is evident that none of the correlations between any of the variables exceeded 0.8. Also, the variables were free from the problem of multi-collinearity. The correlation matrix is shown in Table 4. It is evident from Table 4 that, institutional intervention $(\rho=0.567 ; p<0.01)$ and resource capability $(\rho=0.695 ; p<0.01)$ 


\begin{tabular}{|c|c|c|c|}
\hline & $\overline{\text { Itamno }}$ & Standardized loading & $t$-values \\
\hline & \multicolumn{3}{|l|}{ Community orientation $(\mathrm{CO})$} \\
\hline & COR 7 & 0.572 & 1.000 \\
\hline & ACC 11 & 0.757 & 6.324 \\
\hline & ACC 12 & 0.652 & 6.135 \\
\hline & \multicolumn{3}{|l|}{ Institutional intervention (II) } \\
\hline & II 23 & 0.782 & 1.000 \\
\hline & II 24 & 0.765 & 10.376 \\
\hline & II 25 & 0.776 & 10.449 \\
\hline & \multicolumn{3}{|l|}{ Capability of resources (CR) } \\
\hline & CR 32 & 0.650 & 1.000 \\
\hline & PI 35 & 0.770 & 9.177 \\
\hline & TR40 & 0.813 & 9.554 \\
\hline & TR 41 & 0.739 & 8.880 \\
\hline & \multicolumn{3}{|l|}{ Human capital management (HCM) } \\
\hline & HCM 66 & 0.693 & 1.000 \\
\hline & HCM 67 & 0.874 & 10.651 \\
\hline & HCM 69 & 0.762 & 9.629 \\
\hline & HCM 70 & 0.778 & 9.798 \\
\hline & \multicolumn{3}{|l|}{ CHPS performance (CP) } \\
\hline & CP 42 & 0.699 & 1.000 \\
\hline & CP 43 & 0.716 & 9.216 \\
\hline & СР 46 & 0.646 & 8.374 \\
\hline & CP 48 & 0.807 & 10.261 \\
\hline & CP 50 & 0.683 & 8.880 \\
\hline \multirow{10}{*}{$\begin{array}{l}\text { Table } 3 \text {. } \\
\text { CFA results for } \\
\text { measurement model }\end{array}$} & Goodness-of-fit statistics & Statistics & \\
\hline & Chi-square $\left(\chi^{2}\right)$ & & $\begin{array}{c}11.774 \\
(\mathrm{df}=6 \cdot p=0.067)\end{array}$ \\
\hline & \multicolumn{2}{|c|}{$(\mathrm{df}=6 ; p=0.067)$} & $\begin{array}{c}(\mathrm{u}-0, p-0.00 t) \\
2.902\end{array}$ \\
\hline & \multicolumn{2}{|l|}{$\begin{array}{l}\chi^{2 / \mathrm{df}} \\
\text { Goodness-of-fit index (GFI) }\end{array}$} & 0.836 \\
\hline & \multicolumn{2}{|l|}{ Adjusted goodness-of-fit index (AGFI) } & 0.780 \\
\hline & \multicolumn{2}{|l|}{ Normed fit index (NFI) } & 0.803 \\
\hline & \multicolumn{2}{|l|}{ Comparative fit index } & 0.859 \\
\hline & \multicolumn{2}{|l|}{ Tuker-Lewis index (TLI) } & 0.830 \\
\hline & \multicolumn{2}{|l|}{ Root mean square error of approximation (RMSEA) } & 0.098 \\
\hline & Source: Author's Estimation from Field Survey, 2020 & & \\
\hline
\end{tabular}

has a strong statistically positive relationship with CHPS performance at $(p<0.01)$. HCM $(\rho=0.370 ; p<0.01)$ and community orientation $(\rho=0.295 ; p<0.01)$ showed a positive statistically significant relationship with CHPS performance but it was not that strong.

\section{Hierarchical multiple regression}

The result for the hierarchical multiple regression is shown in Table 5. The tolerance values (of greater than 0.10) and the variance inflation factor values (of less than 5) indicate that there is no multi-collinearity in the data (Hair et al., 2012). These control variables explained $3.5 \%$ of the variances in CHPS performance in Model 1. In Model 2, the addition of the independent variable to the control variable saw the $R^{2}$ increase by $15.5 \%(\Delta F=37.263 ; p<$ 0.001) over the explained variance in CHPS performance in Model 1. In Model 3, the addition of the community orientation, institutional intervention, resource capability and 


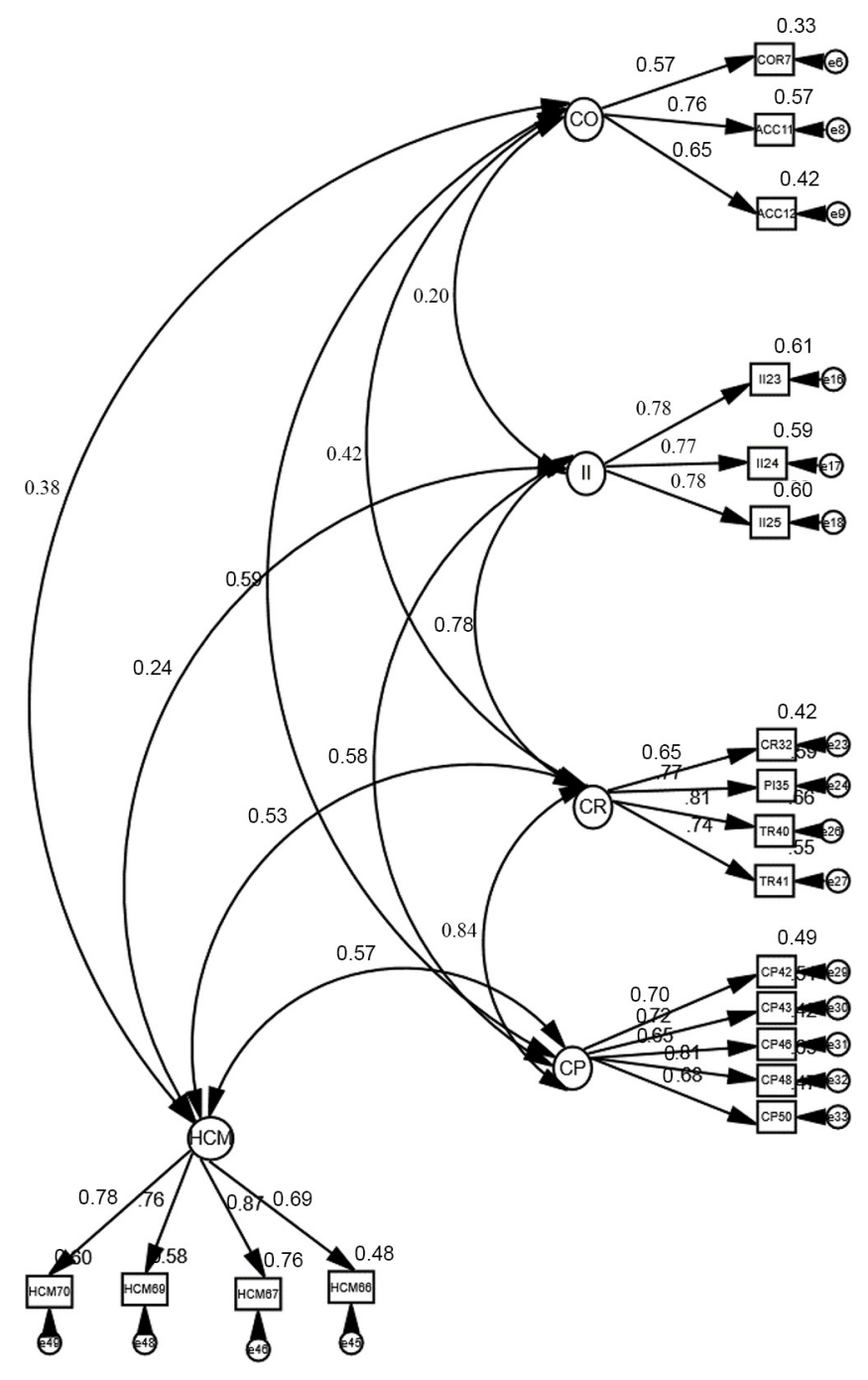

Human capital management

Figure 2. Measurement model

independent variable to the control variable saw the $R^{2}$ increase by $42.3 \%(\Delta F=46.589 ; p<$ 0.001 ) over the explained variance in CHPS performance in Model 2.

Language of the people has a negative impact on the performance of CHPS. The independent variables HCM alone had a statistically significant impact on the performance of CHPS across all models (Model2; $\beta=0.82 ; t=6.100 ;$ Model 3; $\beta=0.365 ; t=5.423$ ). The result means that holding all other factors constant, an increase in the HCM will increase the performance of the CHPS model. Capability of resources $(\beta=0.194 ; t=3.171$; $p<0.01)$ and institutional intervention $(\beta=0.575 ; t=6.725 ; p<0.001)$ showed a positive statistically significant mediating effect on the relationship between HCM and the performance. However, community orientation $(\beta=-0.03 ; t=-0.531 ; p>0.05)$ showed a 
$\mathrm{XJM}$

Figure 3.

Hypothesized models

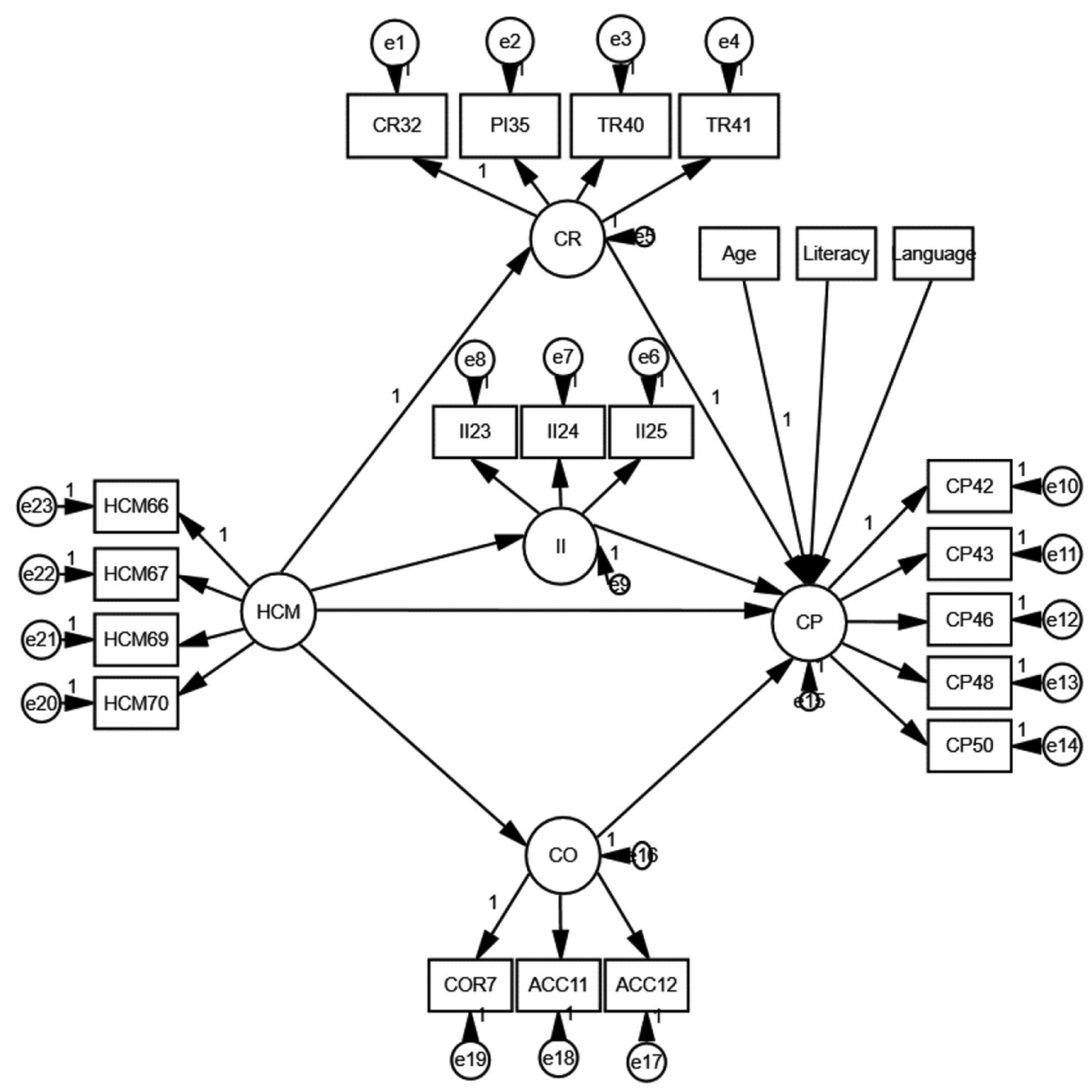

Table 4.

Pearson's correlation matrix results

\begin{tabular}{lllllllll}
\hline Variable & 1 & 2 & 3 & 4 & 5 & 6 & 7 & 8 \\
\hline CHPS Performance & 1 & & & & & & \\
Human Capital Mgt & $0.370^{* *}$ & 1 & & & & & \\
Community Orientation & $0.295^{* *}$ & $0.257^{* *}$ & 1 & & & & & \\
Institutional Intervention & $0.567^{* *}$ & $0.218^{* *}$ & $0.258^{* *}$ & 1 & & & & \\
Capability of Resources & $0.695^{* *}$ & $0.464^{* *}$ & $0.456^{* *}$ & $0.650^{* *}$ & 1 & & & \\
Age Dynamic & 0.036 & 0.056 & -0.109 & -0.007 & 0.051 & 1 & & \\
Literacy Level & -0.050 & -0.048 & 0.034 & 0.014 & -0.071 & $-0.334^{* *}$ & 1 & \\
Culture & 0.070 & 0.135 & $0.192^{* *}$ & -0.006 & 0.032 & -0.107 & 0.014 & 1
\end{tabular}

Notes: ${ }^{+} P<0.10,{ }^{*} p<0.05,{ }^{* *} p<0.01,{ }^{* * *} p<0.001$

Source: Author's Estimation from Field Survey, 2020 


\begin{tabular}{|c|c|c|c|c|c|c|}
\hline CHPS performance $(\mathrm{CP})$ & Model 1 & Model 2 & Model 3 & Tolerance & $\mathrm{VIF}$ & nan cal \\
\hline (Constant) & $4.19(44.62)^{* * *}$ & $1.03(1.96)^{*}$ & $0.271(0.576)$ & & & \\
\hline $\begin{array}{l}\text { Control variable } \\
\text { Age } \\
\text { Literacy level } \\
\text { Language of the people }\end{array}$ & $\begin{array}{l}-0.12(-1.357) \\
-0.06(-0.55) \\
-0.16(-1.76)+\end{array}$ & $\begin{array}{l}-0.14(-1.70)+ \\
0.003(0.03) \\
-0.24(-2.83)^{* *}\end{array}$ & $\begin{array}{c}0.002(0.091) \\
-0.007(-0.178) \\
0.03(0.986)\end{array}$ & $\begin{array}{l}0.885 \\
0.792 \\
0.864\end{array}$ & $\begin{array}{l}1.130 \\
1.263 \\
1.158\end{array}$ & \\
\hline \multicolumn{7}{|c|}{$\begin{array}{l}\text { Independent variables } \\
\text { Human capital management }(\mathrm{HCM})\end{array}$} \\
\hline $\begin{array}{l}\text { Mediating variables } \\
\text { Community orientation (CO) } \\
\text { Institutional intervention (II) } \\
\text { Capability of resource (CR) }\end{array}$ & & & $\begin{array}{l}-0.03(-0.531) \\
0.194(3.171)^{* * *} \\
0.575(6.725)^{* * * *}\end{array}$ & $\begin{array}{l}0.872 \\
0.929 \\
0.438\end{array}$ & $\begin{array}{l}1.146 \\
1.076 \\
2.281\end{array}$ & \\
\hline $\begin{array}{l}R^{2} \\
\text { Adjusted } R^{2} \\
F \text {-value } \\
\text { Changes in } R^{2} \\
\text { Partial } F \text {-value } \\
\text { Df }\end{array}$ & $\begin{array}{l}0.035 \\
0.021 \\
2.394+ \\
0.035 \\
2.394+ \\
3 / 196\end{array}$ & $\begin{array}{l}0.19 \\
0.174 \\
11.444^{* * *} \\
0.155 \\
37.263^{* * *} \\
1 / 195\end{array}$ & $\begin{array}{l}0.613 \\
0.594 \\
29.976 * * * \\
0.423 \\
46.589 * * * \\
3 / 189\end{array}$ & & & Table 5. \\
\hline \multicolumn{6}{|c|}{$\begin{array}{l}\text { Notes: }+P<0.10, * p<0.05, * * p<0.01,{ }^{* * *} p<0.001 \text { ( } t \text {-values for each effect in parentheses) } \\
\text { Source: Author's Estimation from Field Survey, } 2020\end{array}$} & $\begin{array}{l}\text { regression results on } \\
\text { CHPS performance }\end{array}$ \\
\hline
\end{tabular}

negative but statistically insignificant mediation effect on the relationship. Further, the ramsey regression equation specification error test $[0.624(p>0.05)]$ underscores no sign of misspecification in the data.

\section{Discussion, implications and recommendations \\ Discussion of findings}

The study considered the impact of HCM on the performance of the CHPS model. It emerged that there is a direct relationship between HCM and the performance of the CHPS model. This implies that improving the human resources (HR) element of the health sector might result in increased performance for the CHPS model. This finding corroborates previous studies (Malam et al., 2019) in which HCM showed a positive significant relationship with the performance of organizations. Also, HCM improves the uniqueness of employees and also adds value to them. Thus, carefully selecting human resource practices set the precedent to the successful and effective management of organizations.

Institutional intervention and capability of resources were found to positively mediate the hypothesized relationship between HCM and the performance of the CHPS model. However, community orientation showed an inverse mediating role in influencing the relationship between HCM and the performance of the CHPS model. These results imply that with a good repertoire of the capability of resources and institutional interventions, the social skills of staff under the CHPS model could be improved, thus resulting in improved performance. However, community orientation will rather reduce the performance of the CHPS model. This could probably be because of the low awareness or community not properly reoriented to understand the functions of the CHPS model, they might feel the CHPS do not have the needed infrastructure to meet their health needs. 
The findings of the study have significant implications for the decision-makers of the CHPS model and the local communities they serve. Health policymakers need to consider functionality issues undermining an effective implementation of the CHPS model in the targeted areas. Specifically, $\mathrm{HC}$ development must constitute the core of policy reorientations needed to give the model a good footing. Additionally, the findings point to a need for awareness creation on the benefits of the CHPS model at the community level. Consequently, staff working under the CHPS model need to be trained to acquire advocacy skills which is needed to ensure the adequate orientation of members of the targeted communities at various touchpoints.

The positive mediation of resource capability is an indication that managers of the CHPS model must improve infrastructure and build the HR capabilities of the staff. Improvement in infrastructure is critical to harnessing and developing the skill base of the CHPS model workforce to improve performance. Consequently, both infrastructural development and the building of staff capability work in tandem to add value.

\section{Limitations of the study}

The study has coverage errors and non-response biases as limitations due to the unwillingness of respondents to take part in the survey because of current COVID-19 pandemics. Also, the limited access to CHPS zones, which constitute the working place of the sampled population during the survey, was furthermore construed as a type of non-response bias.

\section{Conclusion}

The study concluded that HCM had a significant positive influence on the performance of the CHPS model. This means that building the HC base of the program could help improve performance and meet the envisaged delivery targets. Efforts must be made to create mentorship opportunities for the CHPS model workforce through the establishment of a sister-facility program with nearby major hospitals. Government and non-governmental organizations could be a great source of support for staff development initiatives to build capacity for the CHPS program.

\section{References}

Abor, P.A., Abekah-Nkrumah, G. and Abor, J. (2008), "An examination of hospital governance in Ghana”, Leadership in Health Services, Vol. 21 No. 1, pp. 47-60.

Ali, H., Chaudhry, I.S. and Ali, H. (2016), "Moderating effect of social capital in between human capital and organization performance: case study of service sector of Pakistan", Pakistan Journal of Social Sciences, Vol. 36 No. 2, pp. 1229-1241.

Awoonor-Williams, J.K., Kyei-Onanjiri, M., Carolan-Olah, M. and McCann, T.V. (2018), "Review of emergency obstetric care interventions in health facilities in the Upper East region of Ghana: a questionnaire survey”, BMC Health Services Research, Vol. 18 No. 1, pp. 1-8.

Bandalos, D.L. (2014), "Relative performance of categorical diagonally weighted least squares and robust maximum likelihood estimation", Structural Equation Modeling: A Multidisciplinary Journal, Vol. 21 No. 1, pp. 102-116.

Baron, A. and Armstrong, M. (2007), Human Capital Management: Achieving Added Value through People, London, Kogan Page.

Bontis, N., Dragonetti, N.C., Jacobsen, K., Roos, G. (1999), "The knowledge toolbox: a review of the tools available to measure and manage intangible resources", European Management Journal, Vol. 17 No. 4, pp. 391-402. 
Chatzkel, J.L. (2004), "Human capital: the rules of engagement are changing", Lifelong Learning in Europe, Vol. 9 No. 3, pp. 139-145.

Crook, T.R., Todd, S.Y., Combs, J.G., Woehr, D.J. and Ketchen, D.J. Jr (2011), "Does human capital matter? A meta-analysis of the relationship between human capital and firm performance", Journal of Applied Psychology, Vol. 96 No. 3, pp. 443-456.

Desseler, G. (2007), Human Resource Management, 10th ed., Prentice Hall of India, New Delhi, Pearson Education.

Donate, M.J., Peña, I. and Sanchez de Pablo, J.D. (2016), "HRM practices for human and social capital development: effects on innovation capabilities", The International Journal of Human Resource Management, Vol. 27 No. 9, pp. 928-953.

Doney, P.M. and Cannon, J.P. (1997), "An examination of the nature of trust in buyer-seller relationships”, Journal of Marketing, Vol. 61 No. 2, pp. 35-51.

Grant, D., Michelson, G., Oswick, C. and Wailes, N. (2004), "Guest editorial: discourse and organizational change”, Journal of Organizational Change Management, Vol. 18 No. 1, pp. 6-15.

Gujarati, D.N. (2003), Basic Econometrics, 4th Edition, McGraw-Hill, New York.

Hair, J.F., Sarstedt, M., Pieper, T.M. and Ringle, C.M. (2012), "The use of partial least squares structural equation modeling in strategic management research: a review of past practices and recommendations for future applications", Long Range Planning, Vol. 45 Nos 5/6, pp. 320-340.

Heravi, A., Coffey, V. and Trigunarsyah, B. (2015), "Evaluating the level of stakeholder involvement during the project planning processes of building projects", International Journal of Project Management, Vol. 33 No. 5, pp. 985-997.

Jain, S. and Ahuja, S.K. (2019), "Impact of human capital management practices on employee job performance", University Institute of Management, Vol. 1 No. 1, pp. 268-274.

Kline, R.B. (2005), Principles and Practice of Structural Equation Modeling, 2nd ed., New York, NY, Guilford Press.

Kulkarni, P., Mutkekar, R. and Ingalagi, S. (2020), "Role of strategic management for employee engagement and skill development for start-ups", Vilakshan - XIMB Journal of Management, Vol. 17 Nos 1/2, pp. 79-95.

Kweku, M., Amu, H., Awolu, A., Adjuik, M., Ayanore, M.A., Manu, E., .. Gyapong, J.O. (2020), "Community-based health planning and services plus programme in Ghana: a qualitative study with stakeholders in two systems learning districts on improving the implementation of primary health care", PLoS One, Vol. 15 No. 1, p. e0226808.

Lee, F.H., Lee, T.Z. and Wu, W.Y. (2010), "The relationship between human resource management practices, business strategy and firm performance: evidence from steel industry in Taiwan", The International Journal of Human Resource Management, Vol. 21 No. 9, pp. 1351-1372.

Malam, S.S., Daji, L.B.D. and Ladan, A.A. (2019), "The relationship between organizational culture and employee performance in Nigerian tertiaty institutions: a proposed theoretical framework", Asian Journal of Multidisciplinary Studies, Vol. 7 No. 1, pp. 7-10.

Podsakoff, P.M. and Organ, D.W. (1986), "Self-reports in organizational research: problems and prospects”, Journal of Management, Vol. 12 No. 4, pp. 531-544.

Proenca, E.J., Rosko, M.D. and Zinn, J.S. (2000), "Community orientation in hospitals: an institutional and resource dependence perspective”, Health Services Research, Vol. 35 No. 5, pp. 10-11.

Rudman, R. (2020), Performance Planning and Review: Making Employee Appraisals Work, NJ, Routledge.

Salaman, G., Storey, J. and Billsberry, J. (Eds) (2005), Strategic Human Resource Management: Theory and Practice, NJ, Sage.

Saleh, K. (2012), The Health Sector in Ghana: A Comprehensive Assessment, World Bank Publications, Washington DC.

Saunders, M., Lewis, P. and Thornhill, A. (2012), Research Methods for Business Students, 6th ed., Harlow, Pearson education. 
Taber, K.S. (2018), "The use of cronbach's alpha when developing and reporting research instruments in science education", Research in Science Education, Vol. 48 No. 6, pp. 1273-1296.

Teye, J.K., Awumbila, M. and Owusu, G. (2014), "Can rural-urban migration into slums reduce poverty? Evidence from Ghana”, Open Doc, Vol. 20 No. 5, pp. 12413-14825.

Vroom, V.H. (1964), Work and Motivation, San Francisco, CA, Jossey-Bass.

Wright, P.M., Gardner, T.M. and Moynihan, L.M. (2003), "The impact of HR practices on the performance of business units", Human Resource Management Journal, Vol. 13 No. 3, pp. 21-36.

\section{Further reading}

Armstrong, M. and Taylor, S. (2020), Armstrong's Handbook of Human Resource Management Practice, 13th ed., London, Kogan Page.

\section{Corresponding author}

Rejoice Wodomdedzi Foli can be contacted at: ggwealthconsults@gmail.com

For instructions on how to order reprints of this article, please visit our website: 